\title{
MENENTUKAN KERANGKA KERJA MANAJEMEN PROYEK PERUSAHAAN
}

\author{
Rahayu Ary Yuniarti; Hendra ST
}

\author{
Jurusan Sistem Informasi, Fakultas Ilmu Komputer, Binus University \\ Jl. KH. Syahdan No. 9, Palmerah, Jakarta Barat 11480. \\ ary_yuniarti@binus.ac.id; hendra_st@yahoo.com
}

\begin{abstract}
Every business has a vision for its business plan. Sometimes they face a problem on how to deliver a business plan into a detailed project to achieve their vision. Developing an enterprise project management is one of effective business principles and systems for guiding and organizing that functions to deliver a business plan and to align and integrate processes and information systems. Enterprise project management is a systematic approach for program management and is based on the principle that the vision, mission, and objectives of organization are a set of projects. When effectively defined, planned, integrated, and communicated, business is provided with a totally different view of your organization's ability to define and achieve its objectives. Moving an organization from an old fashioned project management view to the Enterprise Project Management is a shift that is both technical and cultural.
\end{abstract}

Keywords: Project, Project Management, Enterprise, Business

\begin{abstract}
ABSTRAK
Setiap bisnis memiliki visi untuk rencana bisnisnya. Terkadang untuk mencapai visi, masalah tentang bagaimana menyampaikan rencana bisnis ke dalam proyek rinci harus dihadapi. Mengembangkan manajemen proyek perusahaan merupakan salah satu prinsip bisnis yang efektif dan sistem sebagai panduan dan pengatur yang berfungsi untuk memberikan rencana bisnis dan menyelaraskan serta mengintegrasikan proses dan sistem informasi Enterprise Project Management adalah sebuah pendekatan sistematis untuk manajemen program dan berdasarkan pada prinsip bahwa visi, misi, dan tujuan organisasi adalah seperangkat proyek. Ketika secara efektif didefinisikan sebagai terencana, terpadu, dan butuh komunikasi, bisnis disuguhkan dengan pandangan yang sama sekali berbeda kemampuan organisasi Anda untuk menentukan dan mencapai tujuan. Mengubah organisasi dari pandangan manajemen proyek kuno kepada Enterprise Project Management adalah sebuah pergeseran yang bersifat teknis dan budaya.
\end{abstract}

Kata kunci: Proyek, Project Management, Enterprise, Bisnis 


\section{PENDAHULUAN}

Manajemen proyek sudah menjadi masalah yang klasik. Setidaknya hal ini terjadi sampai dengan akhir tahun 2000-an. Manajemen proyek secara tradisional masih terlalu kaku untuk diterapkan seiring dengan perkembangan bisnis/organisasi. Dibutuhkan suatu pendekatan baru yang dinamis dan bisa terus mengikuti tren yang berkembang.

Selanjutnya berkembanglah suatu disiplin untuk mengembangkan suatu framework atau kerangka kerja manajemen proyek untuk skala enterprise. Kerangka kerja dikembangkan bersamasama mulai dari eksekutif, sponsor dan stakeholder lainnya. Kerangka kerja ini langsung diterjemahkan dari business plan dan selanjutnya diterjemahkan menjadi sekumpulan kebijakan dan prosedur. Kerangka kerja ini yang nantinya akan terus dikembangkan sesuai dengan perkembangan bisnis perusahaan.

Tujuan penulisan makalah ini adalah untuk membahas bagaimana mengelola proyek di perusahaan dengan cara membuat sebuah kerangka kerja manajemen proyek di perusahaan. Manfaat yang diharapakan dari tulisan ini adalah meningkatkan pemahaman tentang bagaimana cara mengelola proyek yang baik untuk skala enterprise. Agar pembahasan tidak jauh melebar, makalah ini dibatasi hanya pada cakupan pembahasan tentang bagaimana mengembangkan suatu kerangka kerja manajemen proyek di perusahaan.

\section{METODE}

Penulisan makalah berdasarkan penelitian dari artikel-artikel terkait dengan manajemen proyek, khususnya proyek dalam skala enterprise.

\section{HASIL DAN PEMBAHASAN}

\section{Proyek}

Proyek adalah segala sesuatu yang dikerjakan untuk pertama kalinya. Bisa berupa konstruksi bangunan, bisa juga berupa pekerjaan mengorganisir sesuatu. Berikut adalah beberapa karakteristik suatu proyek: (1) mempunyai tujuan yang unik; (2) bersifat sementara; (3) membutuhkan sumber daya, dan biasanya berasal dari area yang berbeda-beda; (4) harus mempunyai sponsor atau pelanggan utama; (5) melibatkan sesuatu yang tidak tentu. Karena proyek selalu bersifat baru (tidak berulang), hal-hal yang biasanya terjadi dalam suatu proyek adalah: (1) resiko dan perubahan dengan level yang tinggi; (2) kesulitan memperkirakan sumber daya yang diperlukan; (3) kesulitan memperkirakan waktu yang dibutuhkan untuk menyelesaikan suatu proyek.

\section{Batasan Proyek}

Beberapa batasan proyek adalah sebagai berikut: (1) Ruang lingkup, yaitu apa yang ingin dicapai dari pelaksanaan proyek ini, produk atau layanan apa yang sifatnya unik yang diinginkan pelanggan atau para sponsor; (2) Waktu, yaitu berapa lama waktu yang dibutuhkan untuk menyelesaikan proyek. Hal ini juga berhubungan dengan penjadwalan proyek tersebut; (3) Biaya, yaitu berapa biaya yang dibutuhkan untuk menyelesaikan proyek. 


\section{Tingkat Kompleksitas Proyek}

Beberapa dimensi yang menentukan kompleksitas suatu proyek adalah sebagai berikut. Pertama adalah skala proyek. Skala proyek ini bukan hanya sekedar besar atau kecil, tapi area yang terlibat dalam suatu proyek. Semakin banyak area kerja yang terlibat maka tingkat kompleksitas akan semakin tinggi. Proyek akan semakin kompleks jika melibatkan lintas organisasi. Kedua adalah jumlah dari kelompok atau organisasi yang harus dikoordinasikan. Tingkat kompleksitas proyek juga bergantung dari jumlah kelompok atau organisasi yang perlu dikoordinasikan dalam sauatu proyek. Semakin banyak yang perlu dikoordinasikan maka semakin tinggi tingkat kompleksitas proyek tersebut. Dimensi ketiga yaitu keragaman ilmu dan keahlian yang dibutuhkan. Biasanya semakin kompleks suatu proyek, semakin banyak sumber daya yang dibutuhkan.

\section{Manajemen Proyek}

Manajemen proyek adalah cara mengaplikasikan ilmu pengetahuan, keahlian, tools, dan teknik ke dalam aktifitas suatu proyek untuk memenuhi bahkan melebihi apa yang menjadi kebutuhan dan harapan dari stakeholder suatu proyek. Yang termasuk dalam kelompok stakeholder suatu proyek adalah semua orang yang terlibat atau dipengaruhi oleh aktifitas-aktifitas suatu proyek, termasuk para sponsor, tim, staf pendukung, pelanggan, pemasok, bahkan orang-orang yang menjadi pesaing. Suatu proyek mempunyai area-area penting yang menjadi bagian penting suatu proyek yang biasa disebut dengan "Knowledge Area". Untuk menjadi seorang manajer proyek, memiliki kompetensi dalam "Knowledge Area" tersebut sudah menjadi keharusan.

\section{Kerangka Kerja Manajemen Proyek Perusahaan}

Kerangka kerja manajemen proyek perusahaan adalah sekumpulan perangkat, prosedur dan teknik yang terintgrasi, kohesi, dan saling terkait yang dapat digunakan sebagai petunjuk untuk melaksanakan suatu proyek. Kerangka kerja ini dikembangkan sesuai dengan kebutuhan masingmasing proyek, tergantung pada karakteristik proyek yang akan dijalankan. Namun, ada beberapa hal umum yang bisa diterapkan dalam kerangka kerja manajemen proyek secara umum (Gambar 1).

Pertama adalah perencanaan strategis. Perencanaan strategis adalah perencanaan yang terkait dengan tujuan strategis perusahaan. Perencanaan ini biasanya ditetapkan oleh level direktorat. Oleh sebab itu perencanaan strategis ini harus melibatkan para eksekutif atau pemilik perusahaan. Perencanaan strategis ini perlu ditetapkan secara matang, karena keseluruhan tahap selanjutnya sangat bergantung pada perencanaan strategis ini. Selain melibatkan para eksekutif perusahaan, perencanaan strategis ini juga melibatkan para sponsor perusahaan. Para sponsor harus dilibatkan sesuai dengan kepentingan mereka dalam suatu proyek.

Kedua adalah perencanaan proyek perusahaan. Dari perencanaan strategis diturunkan beberapa proyek yang mendukung pencapaian perencanaan strategis yang sudah ditetapkan sebelumnya. Perencanaan proyek ini sudah spesifik untuk masing-masing area kerja, sehingga dibutuhkan suatu organisasi proyek untuk membuat perencanaan proyek-proyek yang akan dijalankan.

Ketiga adalah perencanaan dan pelaksanaan proyek secara khusus. Perencanaan dibuat berdasarkan area-area kerja yang dilibatkan dalam proyek tersebut. Setelah perencanaan dibuat, baik itu dari segi waktu, biaya, kualiatas, dan sumber daya, tahap selanjutnya adalah pelaksanaan proyek secara spesifik. 


\section{Executive Owners}

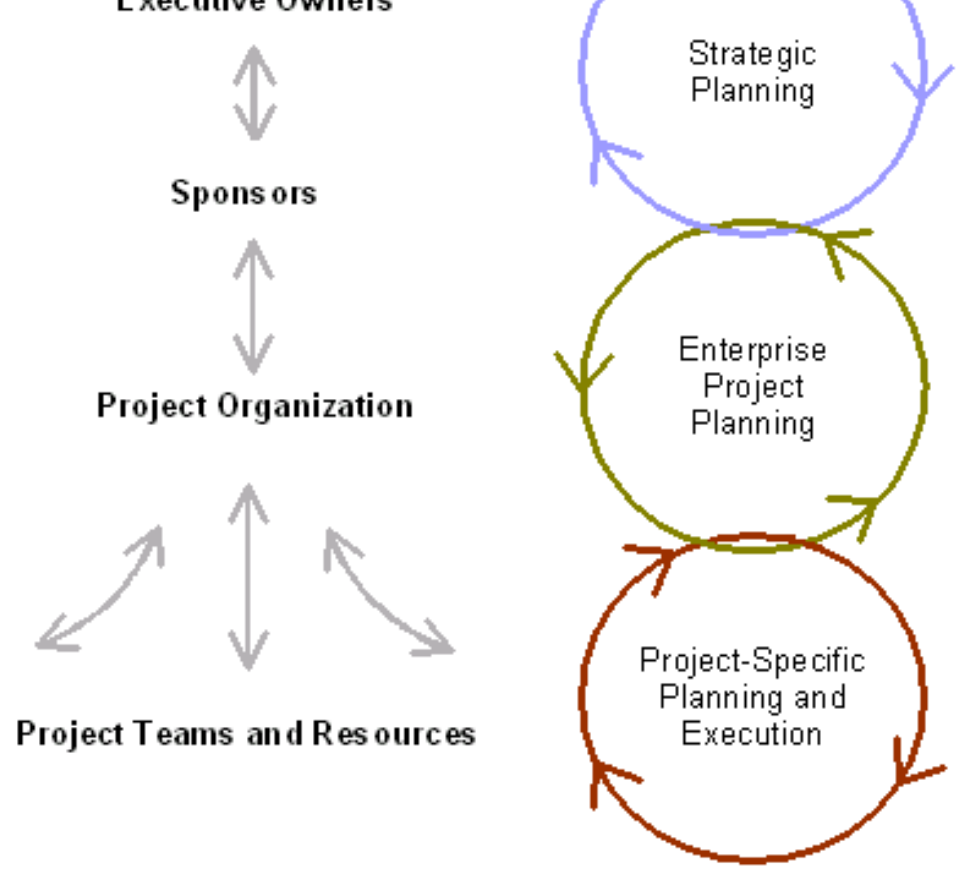

Gambar 1. Alur kerangka kerja manajemen proyek secara umum.

\section{Critical Success Factors suatu Proyek}

Untuk menjamin suatu proyek dapat memenuhi kebutuhan pengguna dan stakeholder, ada beberapa faktor penting yang perlu diperhatikan. Faktor-faktor tersebut masuk dalam kategori Critical Success Factors (CSF) suatu proyek sebagai berikut.

Pertama, definisi tujuan proyek, yang mencakup tujuan, ruang lingkup, batasan, dan kebutuhannya. Hal inilah yang akan menjadi semacam kontrak dalam menjalankan proyek. Proyek dapat dikatakan berhasil jika hasilnya sesuai dengan tujuan, ruang lingkup, batasan, dan kebutuhan yang didefenisikan pada tahap awal pelaksanaan suatu proyek.

Faktor kedua yaitu dukungan dari top management. Keberhasilan suatu proyek juga ditentukan dengan seberapa jauh dukungan yang diberikan oleh top management. Hal ini sangat membantu dalam mengelola proyek dengan baik. Dengan adanya dukungan penuh serta berkelanjutan dari top management, maka akan memudahkan dalam pengempulan data, sosialisasi proyek, dan sebagainya. Misalnya jika top management telah mendukung suatu proyek, proyek tersebut dapat dilegalkan melalui penerbitan suatu policy (kebijakan) yang sifatnya memaksa setiap orang yang terlibat untuk secara aktif memberikan kontribusi pada suatu proyek sesuai dengan kapasitas masingmasing.

Faktor ketiga adalah keterlibatan pengguna. Selain dukungan dari pihak top management, peran pengguna juga menjadi faktor yang sangat penting. Hal ini terlebih terkait dengan hal pengumpulan kebutuhan dan data. Semakin banyak pengguna yang dilibatkan, hasil dari suatu proyek juga akan semakin mendekati kebutuhan pengguna. Kurangnya keterlibatan pengguna sering mengakibatkan hasil akhir suatu proyek itu tidak sesuai dengan kebutuhan pengguna yang padi akhirnya akan manjadi sia-sia. 
Faktor keempat yaitu peran manajer proyek. Peran seorang Manajer Proyek sangat menentukan keberhasilan suatu proyek. Seorang manajer proyek harus benar-benar menguasai atau ahli dalam bidang-bidang yang terkait dengan proyek. Selain itu dibutuhkan juga jiwa kepemimpinan, tanggung jawab, dan kemampuan dalam hal berkomunikasi dengan seluruh anggota proyek dan juga komunikasi kepada pengguna dan stakeholder.

Faktor lainnya juga penting untuk menetukan keberhasilan suatu proyek, seperti sumber daya manusia, perkiraan yang akurat, serta uji coba dan pelatihan.

\section{Tujuh Tahapan Proses Pengait antara Perencanaan Bisnis dengan Delivery Proyek}

Ada tujuh langkah yang bisa dilakukan untuk sukses dalam mengaitkan antara perencanaan bisnis dengan delivery proyek (Gambar 2).

\section{Langkah 1: Evaluasi Kemampuan Dan Tantangan Organisasi}

Fundamental suatu proyek bersifat konstan, namun setiap organisasi memliki kebutuhan yang unik dan tantangan yang perlu dihadapi. Tujuan dari evaluasi ini adalah untuk menentukan bagaimana suatu organisasi itu secara konsisten mendapat tantangan dan solusi seperti apa yang sesuai untuk situasi seperti itu. Hasil dari tahap evaluasi ini adalah sebuah visi dari manajemen proyek perusahaan yang spesifik untuk tiap perusahaan, bersama dengan perkiraan keahlian yang dibutuhkan untuk mengimplementasikan visi seperti itu.

Evaluasi adalah suatu proses yang penting yang menjadi tahapan pertama untuk beralih ke metode manajemen proyek secara enterprise. Tahapan ini harus dapat dimengerti oleh para stakeholder perusahaan, mengetahui tantangan apa saja yang dihadapai perusahaan. Mereka juga harus terlibat secara aktif untuk menentukan visi dari manajemen proyek ini. Salah satu cara yang efektif untuk menciptakan visi dari manajemen proyek perusahaan adalah dengan menterjemahkan perencanaan bisnis menjadi proyek-proyek yang lebih spesifik.

\section{Langkah 2: Rilis Manajemen Proyek Enterprise}

Setelah para eksekutif perusahaan memutuskan apa yang menjadi visi mereka, tahapan selanjutnya adalah membuat komitmen untuk melangkah ke depan. Momen untuk membakukan kerangka kerja manajemen proyek enterprise ini dapat dimulai dengan sesi briefing outline yang menjadi visi dan seberapa besar usaha yang diperlukan untuk menjalankan kerangka kerja ini. Komitmen dari eksekutif dapat ditunjukkan melalui keseriusan dalam penempatan orang-orang yang kompeten dalam kerangka kerja manajemen proyek skala enterprise ini.

Satu bagian penting lainnya adalah para staf yang telah ditetapkan sebagai orang-orang yang mengelola kerangka kerja manajemen proyek ini harus disiapkan baik secara teknikal maupun untuk perubahan cara pikir mereka. Kerangka kerja manajemen proyek yang baru ini harus sudah menjadi budaya mereka.

\section{Langkah 3: Analisis Kebutuhan dari Manajemen Proyek Secara Terperinci}

Ini merupakan langkah awal dalam menterjemahkan visi para eksekutif menjadi rincian berupa solusi praktis. Sama dengan proyek lainnya, tahap pertama dalam penentuan rincian solusi ini adalah dengan menetapkan ruang lingkup dan batasannya. Tahapan selanjutnya adalah dengan 
menentukan mana yang menjadi prioritas dari berbagai kebutuhan yang ada. Solusi yang dihasilkan harus mencakup semua lini organisasi dari tingkat atas sampai bawah.

Defenisinya harus mencerminkan apa yang menjadi visi para eksekutif. Dapat dilihat bahwa hal ini akan berupa kegiatan yang sifatnya iteratif/berulang karena melibatkan hampir semua lini organisasi. Eksekutif perusahaan dan para profesional yang ditetapkan harus berkolaborasi untuk medapatkan pemahaman, penerimaan, dan partisipasi untuk menemukan apa yang menjadi parameter yang sesuai untuk menjadi solusi manajemen proyek di perusahaan mereka.

\section{Langkah 4: Merancang Model Manajemen Proyek Perusahaan}

Fase ini manjadi bagian vital dimana para ahli/professional di perusahan menjalankan perannya. Ada dua area yang menjadi fokus pada fase perancangan ini, yaitu meningkatkan proses yang sudah ada dan mengembangkan proses-proses barus sesuai dengan kebutuhan EPM. Prosesproses penting di perusahaan kemungkinan besar telah didefeniskan sebelumnya. Tujuannya adalah untuk menentukan solusi yang mencakup keseluruhan organisasi yang akan mewakili seluruh organisasi sembari memperoleh keuntungan dari kemampuan dan fitur yang dimilki organisasi.

\section{Langkah 5: Membuat Tools untuk Manajemen Proyek Perusahaan}

Tools yang dimaksudkan dapat berupa kebijakan atau prosedur untuk menjaga konsistensi dalam menjalankan manajemen proyek ini. Tools ini juga dapat dituangkan menjadi suatu perangkat lunak sistem manajemen proyek perusahaan. Dengan adanya tools ini diharapkan perusahaan dapat secara konsisten untuk mengelola proyek dengan baik.

\section{Langkah 6: Melakukan Validasi Model Manajemen Proyek Perusahaan}

Setelah menciptakan konsep yang bagus dan kemungkinan telah dituangkan menjadi suatu perangkat lunak, langkah selanjutnya adalah melakukan pengujian terhadap konsep yang telah ditetapkan bersama. Cara pengujiannya adalah dengan membuat simulasi untuk suatu proyek tertentu.

Ada dua pilihan untuk menetukan mana yang cocok dijadikan sebagai pilot project untuk simulasi. Pilihan pertama adalah suatu proyek yang sudah dalam kondisi 'chaos' dan perlu untuk diperbaiki. Keuntungan dengan memilih proyek ini adalah jika berhasil, model yang ditetapkan telah ternukti teruji bahkan untuk proyek yang paling rumit. Kerugiannya adalah kalau gagal, orang-orang akan memandang dengan sebelah mata.

\section{Langkah 7: Implementasi Model Manajemen Proyek Perusahaan}

Walaupun sudah mempunyai suatu model kerangka manajemen proyek yang baik, yang telah diuji dan hasilnya memuaskan, bukan berarti saat implementasinya tidak mendapat tanggapan yang baik dari semua orang yang terlibat. Untuk itu, diperlukan komitmen dari eksekutif di perusahaan dan tentunya komunikasi yang baik untuk semua lini organisasi. Kerangka kerja manajemen proyek harus menjadi prisnsip dan disiplin yang harus dijalankan perusahaan mulai dari top level sampai dengan bottom.

\section{Pasca Implementasi}

Tujuh tahapan yang sudah didefeniskan sebelumnya harus menjadi fokus untuk menentukan solusi-solusi yang nantinya dapat dengan mudah untuk diadaptasi dan akan meningkatkan kematangan kerangka kerja manajemen proyek yang telah dibuat. Dengan adanya kerangka kerja manajemen proyek yang fundamental, perusahan akan mampu untuk: (1) Mengembangkan strategi, perencanaan, 
dan biaya yang berkelanjutan dan proaktif; (2) Mendefenisikan, inisiasi, perencanaan, dan melaksanakan proyek yang sesuai dengan strategi bisnis; (3) Menentukan skala prioritas dan mengalokasikan sumber daya yang sesuai dengan prioritas peusahaan; (4) Menyediakan pengukuran, komunikasi, dan pelaporan yang konsisten; (5) Menyediakan pendekatan manajemen proyek yang konsisten untuk semua divisi dan departemen.

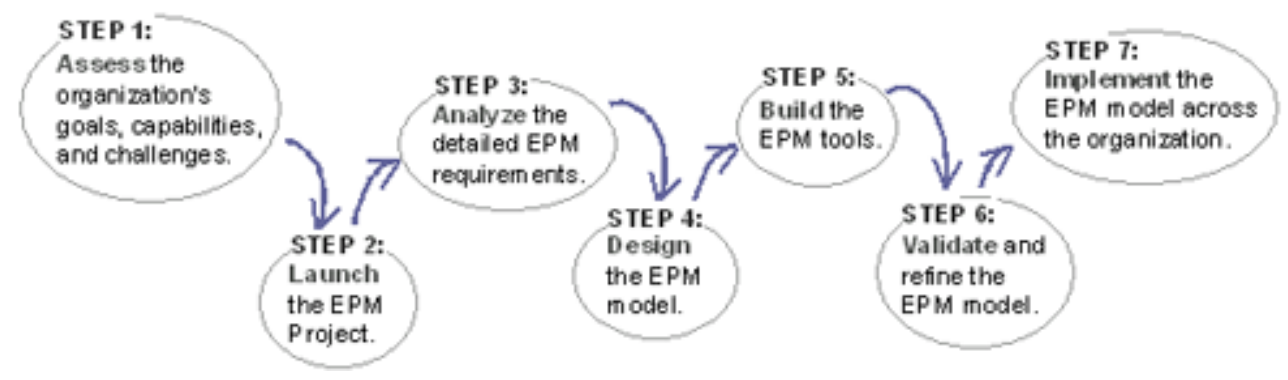

Gambar 2. Tujuh langkah sukses mengaitkan perencanaan bisnis dengan delivery proyek.

\section{PENUTUP}

Proyek adalah segala sesuatu yang dikerjakan untuk pertama kalinya. Proyek selalu bersifat sementara. Manajer proyek adalah individu yang memiliki otoritas, akuntabilitas, dan bertanggungjawab untuk mencapai objektif suatu proyek. Manajemen proyek mengaplikasikan ilmu pengetahuan, keahlian, tools, dan teknik ke dalam aktifitas suatu proyek untuk memenuhi bahkan melebihi apa yang menjadi kebutuhan dan harapan dari stakeholder suatu proyek. Kerangka kerja manajemen proyek adalah sekumpulan perangkat, prosedur dan teknik yang terintgrasi, kohesi, dan saling terkait yang dapat digunakan sebagai petunjuk untuk melaksanakan suatu proyek. Manajemen proyek dalam suatu perusahaan harus dikelola dengan baik. Salah satu caranya adalah dengan menentukan suatu kerangka kerja manajemen proyek perusahaan yang akan menjadi acuan untuk seluruh organisai untuk mengelola proyek baik untuk skala enterprise, divisi, hingga departemen.

\section{DAFTAR PUSTAKA}

Olson, David L., 2003, Introduction to Information Systems Project Management (2nd ed.). New York: McGrawHill.

Schwalbe, Kathy. (2003). Information Technology Project Management (3rd ed.). Kentucky: Course Technology. 